\title{
GAMBARAN PENGETAHUAN REMAJA PUTRI TENTANG PREMENSTRUASI SYNDROME DI SMP NEGERI 29 PEKANBARU
}

\author{
Pratiwi Gasril ${ }^{1}$, Yeni Devita², Erin Erana Putri ${ }^{3}$ \\ 1. pratiwi@umri.ac.id, D osen Keperawatan Universitas Muhammadiyah Riau \\ 2. Staf Dosen ST IKes Payang N egri Pekanbaru \\ 3. Alumni Keperawatan STIK es Pekanbaru M edical Center
}

\begin{abstract}
ABSTRAK
Pengetahuan pada dasarnya terdiri dari sejumlah fakta dan teori yang memungkinkan seseorang untuk dapat memecahkan masalah yang dihadapinya. Pre Menstruasi syndrome adalah penanpilan serampaian gejala yang bersifat siklus sebelum menstruasi yang mempengaruhi gaya hidup dan pekerjaan. M engetahui gambaran pengetahuan remaja putri tentang Pre Menstruasi Syndrome pada Siswa SM PN 29 Kota Pekanbaru. Desain penelitian merupakan bentuk rancangan yang umumnya digunakan dalam melakukan prosedur penelitian. Dengan jumlah sampel sebanyak 99 responden. nstrumen penelitian ini terdiri dari kuisoner yang berisi kusioner. Analisis yang digunakan adalah analisis Univariat. Hasil penelitian menunjukkan Didapatkan rata-rata Rata-rata tingkat pengetahuan Premenstruasi Syndromedari ketiga tingkat pengetahuan yang paling banyak adalah tingkat pengetahuan sedang yaitu (195,65\%). Dari nilai-nilai tersebut didapat disimpulkan bahwa hipotesis penelitain diterima berarti Rata-rata tingkat pengetahuan Premenstruasi Syndromedari ketiga tingkat pengetahuan yang paling banyak adalah tingkat pengetahuan sedang yaitu $(195,65 \%)$.
\end{abstract}

Kata Kunci : Pengetahuan, Remaja, Premenstruasi Syndrome

\section{ABSTRACT}

Knowledge basically consists of a number of facts and theories that allow a person to be able to solve its problems. Pre M enstrual Syndrome is a symptom serampaian appearance before the menstrual cycle that is affecting the lifestyle and work. Know the description of knowledge about the young women Premenstrual Syndrome in Students SM PN 29 Pekanbaru The study design is a form of design which is commonly used in conducting the research procedure. With a total sample of 99 respondents. The research instruments consisted of a questionnaire containing a questionnaire. The analysis is univariate analysis. Obtained results showed average average level of knowledge of premenstrual syndrome of the third level of knowledge the most is the level of knowledge was that (195.65\%). From these values obtained concluded that the hypothesis is accepted penelitain mean average level of knowledge of premenstrual syndrome of the third level of knowledge the most is the level of knowledge was that (195.65\%).

Kata Kunci : Knowledge, Y outh, Premenstruasi Syndrome 


\section{LATAR BELAKANG}

Sekitar 60 juta jiwa penduduk Indonesia adalah remaja. Permasalahan remaja yang ada saat ini sangat kompleks dan mengkhawatirkan. Berbagai data menunjukkan bahwa penerapan pemenuhan reproduksi bagi remaja belum sepenuhnya mereka dapatkan antara lain dalam hal pemberian informasi.H al ini dapat dilihat dari masih rendahnya pengetahuan remaja tentang kesehatan reproduksi yaitu tentang masa subur (BKKBN, 2008).Remaja merupakan masa peralihan atau transisi dari masa kanak-kanak kemasa dewasadalam ilmu kedokteran, remaja dikenal sebagai suatu tahap perkembangan fisik (muncul tandatanda seksual) dan perubahan psikologi (Sarwono, 2008).

Remaja merupakan harapan bangsa, sehingga tidak berlebihan jika dikatakan bahwa masa depan bangsa yang akan datang ditentukan pada masa remaja saat ini. Remaja yang sehat dan berkualitas menjadi perhatian serius bagi orangtua, praktisi pendidikan, ataupun remaja itu sendiri.Remaja yang sehat adalah remaja yang produktif dan kreatif sesuai dengan tahap perkembangannya.Oleh karena itu, pemahaman terhadap tumbuh kembang remaja menjadi sangat penting untuk menilai keadaan remaja (Tarwoto et al, 2010).

Pada remaja putri, akan terjadi proses menstruasi sebagai tanda telah berfungsinya ovarium.M enstruasi terjadi karena sel telur yang tidak dibuahi oleh sperma sehingga menyebabkan seluruhnya sel-sel endometrium dalam rahim.Siklus menstruasi rata-rata adalah 28 hari.Siklus menstruasi ini melibatkan beberapa tahap yang dikendalikan oleh interaksi hormon.Ketidakseimbangan hormone akibat interaksi ini kadang-kadang menimbulkan ketidaknyamanan pada wanita sebelum datang menstruasi yang dikenal dengan istilah Pre M enstruasi Syndrome (Kinanti, 2009).Pada masa remaja khususnya remaja putri akan mengalami perubahan fisik yang pesat, sebagai pertanda biologis dari kematangan seksual.Perubahan ini terjadi pada satu masa disebut masa pubertas, yang merupakan masa transisi antara masa kanak-kanak dan masa reproduksi (Wiknjosastro, 2006).

Penelitian yang dilakukan oleh pelayanan kesehatan ramah remaja (PKRR) dibawah naungan WHO tahun 2005 menyebutkan bahwa permasalahan remaja di Indonesia yang mengalami gangguan menstruasi diperkirakan sebesar $38,45 \%$ (Setiasih, 2007). M asa remaja merupakan periode yang paling rawan dalam perkembangan hidup seorang manusia setelah ia mampu bertahan hidup dimana secara fisik ia mengalami perubahan yang spesifik dan secara psikologi akan mencari identitas diri (Sarwono, 2007).

Pre Menstruasi Syndrome merupakan gangguan berulang yang terjadi pada fase luteal dari siklus menstruasi yang ditandai dengan perubahan fisik,psikologis dan perilaku yang dapatmempengaruhihubungan interpersonal. Pre Menstruasi Syndromedapat terjadi beberapa hari sampai beberapa minggu sebelum menstruasi dan mereda setelah periode menstruasi muncul.Lebihdari $85 \%$ wanita usia subur mengalami ketidaknyamananfisik maupun psikologis beberapa hari sebelum menstruasi yang dapat mempengaruhi kualitas hidup dan produktifitasnya sehari-hari (W ong, 2011). 
Prevalensi Pre M enstruasi Syndrome sebanyak 30 terjadi pada wanita usiasubur, sebanyak 99,5\% remaja minimal mengalami satu gejala pre menstruasi. Penelitian Delara (2013), menunjukkan bahwa 66,3\% remaja dengan Pre Menstruasi Syndrome ringan, 31,4\% dengan Pre M enstruasi Syndrome sedang dan 2,3\% dengan Pre Menstruasi Syndrome berat. Gejala Pre Menstruasi Syndrome dapat mempengaruhi aktivitas sehari-hari sebanyak $90 \%$ wanita menstruasi, gejala tersebut diperkirakan terjadi secara reguler pada dua minggu periode sebelum menstruasi. $\mathrm{Hal}$ ini dapat hilang begitu dimulainya pendarahan, namun dapat pula berlanjut setelahnya. Sekitar 14\% perempuan antara usia 20-35 tahun (Eva, 2010).

Pre Menstruasi Syndrome sedang hingga berat lebih banyak dialami oleh wanita usia remaja dibandingkan wanita usia dewasa yang berada didaerah pasca bencana gempa (Eva, 2010). Penyebab Pre Menstruasi Syndrome belum diketahui secara pasti, diperkirakan dipengaruhi oleh faktor biologi, psikologi, lingkungan dan sosial. Faktor biologi meliputi ketidak seimbangan hormon, ketidak normalan respon neurotrans mitter. Aspek multi dimensional yang diduga sebagai penyebab Pre M enstruasi Syndrome yaitu faktor biopsikososial (Pilliteri, 2010).

Timbulnya gejala Pre M enstruasi Syndrome kemungkinan besar dipengaruhi oleh tingkat pengetahuan tentang kesehatan. $\mathrm{H}$ al tersebut sebagaimana disampaikan oleh peneliti yang dilakukan oleh Windayanti (2007), sebanyak 75\% remaja putri memiliki pengetahuan yang sedang terhadap Pre Menstruasi Sindrome artinya bahwa seseorang yang tidak memiliki pengetahuan tentang kesehatan di ri yang cukup akan cenderung mengabaikan kesehatan dirinya dan pada akhirnya ia akan memilih tindakan yang membahayakan bagi dirinya sendiri. Dengan kata lain karena tidak memiliki pengetahuan yang memadai tentang kesehatan reproduksi maka seseorang akan mudah berperilakuyang membahayakan kesehatan alat-alat reproduksinya. M aka seseorang yang memiliki pengetahuan tentang kesehatan reproduksi akan memilih perilaku yang tepat, artinya perilaku tersebutakan mampu mempertahankan kualitas atau kondisi kesehatan reproduksinya. Jika terkait dengan menstruasi maka yang akan dipilih adalah berperilaku higienis pada saat menstruasi (Windayanti, 2007).

Gejala yang sering dikeluhkan remaja adalah gejala emosional seperti mudah tersinggung, depresi, mudah marah, cemas atau tegang, perubahan suasana hati, sedangkan gejala fisik adalah payudara tegang, perut kembung, sakit kepala dan mudah lelah (Wong, 2011). Dampak dari Pre Menstruasi Syndrome juga mengganggu hubungan keluarga, kerja, aktivitas sosial. Wanita yang mengalami Pre Menstruasi Syndromemelaporkan bahwa gejala Pre Menstruasi Syndrome mempengaruhi kehidupanrumah tangga (30\%) termasuk hubungan dengan suami dan anaknya, mempengaruhi kehidupan sosial $(24,5 \%)$, dan mempengaruhi hubungan teman kerja atau keluarga $(23,1 \%)$ (Kitamura, 2012).

M enurut Manuaba (2009), peran orang tua khususnya ibu, diharapkan mampu memberikan informasi yang tepatdan benar tentang apakah menstruasi itu. Jika mengetahui informasi yang benar tentang menstruasi maka anak remaja perempuan akan merasa siap ketika mendapatkan menstruasi pertama kali. 
Faktor pendidikan seputar menstruasi mempengaruhi kesiapan anak perempuan menjelang remaja untuk menghadapi menarche.

Pendidikan seputar menstruasi disarankan untuk diterapkanbagi anak remaja perempuan yang belum mengalami menstruasi sebagai salah satu cara untuk menumbuhkan kesiapan menghadapimenarche. Selanjutnya jika individu tahu hal apa saja yang harus dilakukan pada saat mengalami kondisi yang sama, misalnya bagaimana cara mengatasi keluarnya darah menstruasi yang dapat terjadi sewaktu-waktu, bagaimana cara memakai dan mencuci pembalut, serta bagaimana cara perawatan diri pada saat menstruasi, maka dapat diharapkan individu mampu berperilaku dengan baik saat menghadapi menstruasi ( $M$ anuaba, 2009).

Hasil survey menunjukkan bahwa Pre M enstruasi Syndrome merupakan masalah kesehatan umum yang paling banyak dilaporkan oleh wanita usia reproduksi, pada saat ini diperkirakan prevalensi dari gejala klinis yang berarti adalah sekitar $12,6 \%$ sampai $31 \%$ dari wanita yang mengalami menstruasi (Freeman, 2007). Hasil penelitian Atieh (2012), menunjukkan bahwa remaja dengan Pre Menstruasi Syndrome mempengaruhi penampilan akademiknya $(60,1 \%)$, remaja meninggalkan sekolah minimal satu hari (43,5\%) dan $22 \%$ mengalami kegagalan dalam ujian. Pre Menstruasi Syndrome juga mempengaruhi pekerjaan rumah $(48,9 \%)$, dan kesulitan konsentrasi $(60,4 \%)$.

Berdasarkan hasil studi pendahuluan yang telah peneliti lakukan di SM PN 29 Pekanbaru pada tanggal 12 N ovember 2015, dari hasil survey 10 orang siswa yang telah dilakukan survei terdapat 8 orang siswa yang tidak mengetahui tentang Pre Menstruasi Syndrome.2 orang siswa sudah mengetahui tentang Pre Menstruasi Syndrome. Berdasarkan fenomena diatas peneliti tertarik meneliti tentang "Gambaran Pengetahuan Remaja Putri tentang Pre Menstruasi Syndrome Di SMPN 29 Pekanbaru tahun 2015”

\section{PEMBAHASAN}

Pengetahuan merupakan hasil dari "tahu" dan ini terjadi setelah orang melakukan penginderaan terhadap objek tertentu. Penginderaan terjadi melalui panca indera manusia, yakni indera penglihatan, pendengaran, penciuman, rasa dan raba. Sebagian besar, pengetahuan manusia diperoleh dari mata dan telinga (N otoatmodjo, 2011).

Pearson(2005) menyatakan bahwa semakin tinggi pengetahuan seseorang, maka semakin mudah untuk menerima informasi sehingga makin banyak pula pengetahuan yang dimiliki sehingga dapat berfikir lebih kritis dalam memahami sesuatu. Menurut teori WHO(World Health Organization) yang dikutip oleh Notoatmojo (2007), salah satu bentuk objek kesehatan dapat dijabarkan oleh pengetahuan yang diperoleh dari pengalaman sendiri.

\section{METODE}

Desain penelitian merupakan bentuk rancangan yang umumnya digunakan dalam melakukan prosedur penelitian (Hidayat, 2007). Menurut Nursalam (2003) desain penelitian adalah sesuatu yang sangat penting dalam penelitian, yang memungkinkan kontrol beberapa faktor yang bisa mempengaruhi akurasi 
suatu hasil. Penelitian ini merupakan penelitian kuantitatif dengan menggunakan desain penelitian deskriptif sederhana yang bertujuan untuk menggambarkan tingkat pengetahuan responden tentang Pre Menstruasi Syndrome. Sedangkan menjadi sub variabelnya adalah pengetahuan tentang Pre M enstruasi Syndromeyang meliputi pengertian, pengetahuan Siswa SM PN 29 Pekanbaru.

Berdasarkan penelitian tentang Pengetahuan remaja putri tentang Pre M enstruasi Syndrome pada siswi SM PN 29 Pekanbaru tanggal 16 -18 Febuari 2016 di dapatkan hasil sebagai berikut:

Tabel 4.1 Distribusi frekuensi responden berdasarkan karakteristik usia responden di SMPN 29 Pekanbaru $(n=99)$ Karakteristik umur Frekuensi Persentase

\begin{tabular}{|c|c|c|c|}
\hline \multicolumn{2}{|c|}{ Karakteristik umur } & Frekuensi & Persentase \\
\hline a. & 11 tahun & & $4,34 \%$ \\
\hline b. & 12 tahun & 40 & $173,91 \%$ \\
\hline c. & 13 tahun & 48 & $208.69 \%$ \\
\hline d. & 14 tahun & 10 & $43,47 \%$ \\
\hline
\end{tabular}

Berdasarkan table 4.1 menjelasakan karakteristik responden berdasarkan usia dapat diketahui bahwa responden terbanyak adalah usia 13 tahun yaitu 48 responden (208,69\%).

Tingkat penegtahuan | Frekuensi Persentase

Table 4.2Distribusi frekuensi responden berdasarkan karakteristik tingkat pengetahuan responden di SM PN 29 Pekanbaru $(n=99)$

Berdasarkan tabel 4.2 menjelaskan karakteristik responden berdasarkan tingkat pengetahuan, dapat

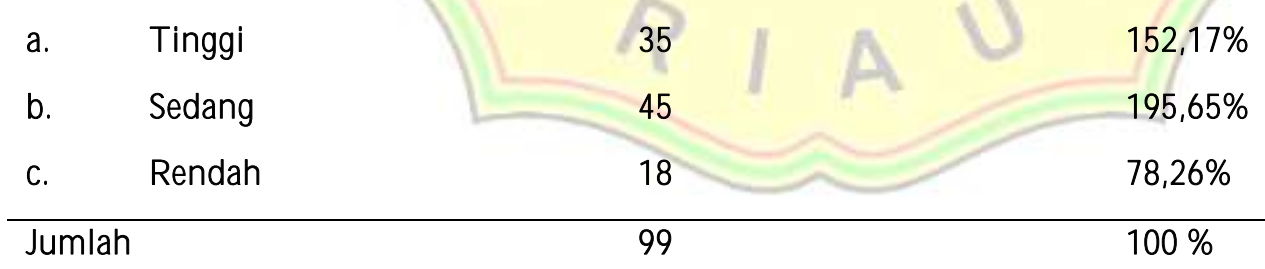

diketahui bahwa responden terbanyak adalah tingkat pengetahuan sedang yaitu 45 responden (195,65\%).

Berdasarkan hasil penelitian yang dilakukan kepada 99 responden, diketahui bahwa jumlah responden perempuan yang berusia 11 tahun 1 responden (4,34\%). Yang berusia 12 tahun adalah 40 responden (173,91\%). Yang berusia13 tahun 48 responden (208,69\%). Dan yang berusia 14 tahun 10 responden (43,47\%).M enurut Depkes RI yang dikutip oleh $\mathrm{H}$ ardiwinoto 12-16 tahun masa remaja awal Masa dimana peralihan diantar masa kanak-kanak kemasa dewasa.

Dalam masa ini anak mengalami masa pertumbuhan dan masa perkembangan fisiknya mau pun perkembangan psikisnya. Seperti mengalami menstruasi, pertumbuhan payudarah, pertumbuhan bulu 
yang halus, dan pertumbuhan ketinggian badan, dan mempunyai pengaruh pada pengetahuan seseorang. Seseorang memperoleh suatu kebudayaan dalam hubungannya dengan orang lain, karena hubungan ini seseorang mengalami suatu proses belajar dan memperoleh suatu pengetahuan. Dari hasil penelitian yang dilakukan pada responden remaja putri setelah membagikan Kuesionerter dapat gambaran tingkat pengetahuan adalah tinggi $152,17 \%$ sedang $195,65 \%$ dan rendah $78,26 \%$ dari ketiga tingkat pengetahuan ini yang paling banyak adalah tingkat pengetahuan sedangyaitu $(195,65) \%$

Pengetahuan merupakan hasil dari "tahu" dan ini terjadi setelah orang melakukan penginderaan terhadap objek tertentu. Penginderaan terjadi melalui panca indera manusia, yakni indera penglihatan, pendengaran, penciuman, rasa dan raba. Sebagian besar, pengetahuan manusia diperoleh dari mata dan telinga (N otoatmodjo, 2011).

\section{KESIMPULAN DAN SARAN}

Setelah dilakukan penelitian tentang pengetahuan Pre menstruasi Syndrome di SMPN 29 Pekanbaru dapat di simpulkan bahwa: Usia yang terdapatdari 99 responden yaitu usia 13 tahun 48 responden (208,69\%). Frekuensi berdasarkan Tingkat pengetahuan responden Rata-rata tingkat pengetahuan Premenstruasi Syndrome dari ketiga tingkat pengetahuan yang paling banyak adalah tingkat pengetahuan sedang yaitu $(195,65 \%)$, tinggi $(152,17 \%)$, rendah $(78,26 \%)$.

Penelitian ini diharapkan dapat dijadikan sebagai wadah bagi peneliti untuk menerapkan ilmu yang telah didapatkan selama perkuliahan dengan mengaplikasikannya secara langsung.

\section{DAFTAR PUSTAKA}

A.M , Sardiman. (2007). Interaksi \& M otivasi Belajar Mengajar. Jakarta : Rajawali Pers

B. Uno, Hamzah. (2007). Teori M otivasi \& Pengukurannya. Jakarta : Bumi Aksara

H astono, Sutanto P. \& Sabri, Luknis. (2010). Statistik Kesehatan. Jakarta : Rajawali Pers

Hidayat, D ede Rahmat. (2009). IImu Perilaku M anusia. Jakarta : TIM

Hidayat, A. Aziz Alimul. (2012). Riset Keperawatan dan Teknik Penulisan I/miah. Jakarta : Salemba M edika

Kemensetneg. (2009). Kebijakan Pemerintah di Bidang Pendidikan. Diakses tanggal 11 Oktober 2015 dari http ://www.setneg.go.ig/index.php? option=com_content \&task=view\&id=3647.html

Latipah, Eva. (2012). Pengantar Psikologi Pendidikan. Yogyakarta : Pedagogia

Notoatmodjo. (2010). I/mu Perilaku Kesehatan. Jakarta: Rineka Cipta

Notoatmodjo. (2012). M etodologi Penelitian Kesehatan. Jakarta : Rineka Cipta

Nuh, M ohammad. (2013). Standar Nasional Pendidikan Tinggi (SNPT). Jakarta : Dirjen Dikti

Pratama, A gam. (2012). M DG's 2015 Tantangan Indonesia Wujudkan Pendidikan Universal.. Diakses tanggal 04 Oktober 
https://www.academia.edu/2359191/M DGs_2015_Tantangan_Indonesia_Wujudkan_Pendidikan_Univ ersal.html

Saam, Zulfan \& W ahyuni, Sri. (2013). Psikologi Keperawatan. Jakarta : Rajawali Pers

Setiadi. (2007). Konsep \& Penulisan Riset Keperawatan. Yogyakarta : Graha IImu

Shaleh, A bdul R. (2009). Psikologi Suatu Pengantar dalm Perspektif Islam. Jakarta : Kencana

Soemanto, W asty. (2012). Psikologi Pendidikan_. Jakarta : Rineka Cipta

Sriyanti, Lilik. (2013). Psikologi Belajar. Yogyakarta : O mbak Dua

Susilo, Rakhmat. (2011). Pendidikan Kesehatan dalam Keperawatan. Yogyakarta : Nuha M edika

Suwarto. (2010). Perilaku Keorganisasian. Yogyakarta : U niversitas A tma J aya

Syah, M uhibbin. 2011. Psikologi Pendidikan. Bandung: PT Remaja Rosdakarya Offset

Tim Kurikulum dan Pembelajaran. 2014. Kurikulum Pendidikan Tinggi. Jakarta : Dirjen Dikti

Utari, Rahmania. 2013. Kebijakan - Kebijakan Pendidikan Formal. Yogyakarta: UNY 